\title{
LUT
}

University

Recovery of indium from indium tin oxide by solvent extraction

\author{
Virolainen Sami, Ibana Don, Paatero Erkki
}

This is a Final draft

version of a publication

published by Elsevier

in Hydrometallurgy

DOI: 10.1016/j.hydromet.2011.01.005

Copyright of the original publication: () 2011 Elsevier B.V.

Please cite the publication as follows:

Virolainen, S., Ibana, D., Paatero, E. (2011). Recovery of indium from indium tin oxide by solvent extraction. Hydrometallurgy, vol. 107, iss. 1-2, pp. 56-61. DOI: 10.1016/j.hydromet.2011.01.005

This is a parallel published version of an original publication.

This version can differ from the original published article. 


\section{Recovery of indium from indium tin oxide by solvent extraction}

Article in Hydrometallurgy · April 2011

DOI: 10.1016/j.hydromet.2011.01.005

3 authors, including:

\section{Sami Virolainen}

Lappeenranta University of Technology 18 PUBLICATIONS 92 CITATIONS

SEE PROFILE
Don Ibana

Curtin University

15 PUBLICATIONS 137 CITATIONS

SEE PROFILE 


\title{
Recovery of Indium from Indium Tin Oxide by Solvent Extraction
}

\author{
Sami Virolainen ${ }^{a, *}$, Don Ibana ${ }^{\mathrm{b}}$, Erkki Paatero ${ }^{\mathrm{a}, \mathrm{c}}$ \\ ${ }^{a}$ Lappeenranta University of Technology, Laboratory of Industrial Chemistry, P.O. Box 20, FI-53851 \\ Lappeenranta, Finland \\ ${ }^{\mathrm{b}}$ Curtin University of Technology, Western Australian School of Mines, Locked Bag 22, Kalgoorlie WA 6433, \\ Australia \\ ${ }^{c}$ Outotec Oyj, Riihitontuntie 7E, P.O. Box 86, FI- 02201 Espoo, Finland \\ *Corresponding author. Tel.: +358 40 7093444, fax: +358 56212199. \\ E-mail address: sami.virolainen@lut.fi
}

\section{Abstract}

Recovery of indium from LCD screen wastes, which contain indium in the form of indium tin oxide (ITO) as the electrode material, is becoming economically and environmentally justified. LCD screens. Indium is a valuable metal and the present work was aimed to recover indium from ITO as the starting material to study the recovery of indium from waste LCD screens by solvent extraction.

The apparent rate of dissolution in acidic media is slow requiring six hours for complete dissolution of the ITO sample in $1 \mathrm{M}$ of either $\mathrm{H}_{2} \mathrm{SO}_{4}$ or $\mathrm{HCl}$. Complete dissolution in $\mathrm{HNO}_{3}$ took significantly longer. The acid concentration was found to have a major effect on both the amount and rate of leaching allowing some leaching selectivity.

Three solvent systems were chosen to study their selectivity for separation of indium from tin: TBP, D2EHPA and a mixture of both. With either $1 \mathrm{M}$ TBP or $0.2 \mathrm{M}$ D2EHPA + 0.8 M TBP, tin could be selectively extracted from a $1.5 \mathrm{M} \mathrm{HCl}$ solution of this metal. D2EHPA extracts both indium and tin from $\mathrm{H}_{2} \mathrm{SO}_{4}$ media but indium could be selectively stripped with $\mathrm{HCl}$ from the loaded D2EHPA. Based on these results, a scheme for separating and concentrating indium from ITO by solvent extraction is proposed. The scheme includes dissolving ITO into $1 \mathrm{M} \mathrm{H}_{2} \mathrm{SO}_{4}$, then extracting indium and tin to D2EHPA followed by selective stripping of indium into $1.5 \mathrm{M} \mathrm{HCl}$. With this process, $\mathrm{HCl}$ solution containing $12.2 \mathrm{~g} / \mathrm{L}$ of indium could be achieved. 


\section{Introduction}

Indium is a rare and valuable metal, which is used mainly as indium tin oxide-films (84\% in 2007) in liquid crystal displays (LCDs) [1]. These indium tin oxide (ITO) films are composed of $90 \%$ of $\mathrm{In}_{2} \mathrm{O}_{3}$ and $10 \%$ of $\mathrm{SnO}_{2}$. New types of solar panels containing indium are being developed and they may become an important application sector for indium in the future [2] potentially increasing the demand for indium.

Indium is evenly distributed in the earth's crust. It has no minerals of its own so it has to be recovered as a byproduct from other metallurgical processes or from secondary raw materials. Most commonly indium is associated with zinc, lead, copper, and tin ores [3-5]. In the $21^{\text {st }}$ century, the price has been at its lowest (below $100 \mathrm{USD} / \mathrm{kg}$ ) in 2002 and highest (over $1000 \mathrm{USD} / \mathrm{kg}$ ) in 2005. Currently, the price is around the $535 \mathrm{USD} / \mathrm{kg}$ [6].

The largest indium producer is China with other big suppliers being South Korea, Japan, Canada, Belgium, Russia, France and Peru. China also has by far world's biggest indium reserves. The global refinery production of indium was 568 ton in $2008[1,2]$.

Today the amount of waste LCD screens from computer and TV sets is fast accumulating owing to the popularity of their usage particularly in consumer goods and thus, development of recovery methods for indium from these wastes is growing in importance. Since 2007 more indium has been produced from secondary than from primary raw materials. The most important secondary raw material has been the waste coming from the sputtering process in the deposition of ITO onto the LCDs, in which only $30 \%$ of ITO is deposited onto the glass surface [1,2]. From the sputtering waste indium can be recovered by dissolving it in $\mathrm{HCl}$ and then precipitating it with $\mathrm{NaOH}$ [7]. A few methods have been patented for recovering indium from secondary ITO waste (used LCDs). The methods of Lee et al. [8] and Chen et al. [9] are based on leaching and precipitation. As in any precipitation techniques, these methods are limited by the solubility equilibrium of the 
hydroxide. Shimofusa et al. [10] have patented a method in which indium is recovered by solvent extraction from nitric acid solution, which includes heavy metals as impurity but the use of nitric acid is expensive. Clearly, there remains a need to develop a more efficient method of recovering indium from waste LCDs.

\section{Solvent extraction of indium}

Solvent extraction is a commonly used method for the purification of indium in process metallurgy particularly in zinc refineries, where indium is usually recovered from sulfate solutions [11]. The research in the solvent extraction of indium started in early 1960s [12]. The earliest patents and articles about the use of solvent extraction in the hydrometallurgical recovery of indium were published in the early 1980s [13-15]. Several extractant types have been used in the extraction of indium including carboxylic acids, phosphoric acid derivatives, chelating compounds like hydroxyoximes and azoles, and solvating extractants such as tributyl phosphate (TBP), trioctylphosphine oxide (TOPO) and methyl isobutyl ketone (MIBK). See Paiva [12] for a good review.

Bis(2-ethylhexyl) phosphate (CAS-number 298-07-7), usually known as di-2ethylhexylphosphoric acid (D2EHPA), is by far the most popular extractant and it is almost always used in practical applications since it has a high loading capacity for indium and good selectivity for indium over many other metal ions such as, for example, $\mathrm{Zn}(\mathrm{II}), \mathrm{Fe}(\mathrm{II}), \mathrm{Cd}(\mathrm{II})$, $\mathrm{As}(\mathrm{III})$ and $\mathrm{Cu}(\mathrm{II})$ [14-16]. Sato et al. [17,18] reported a comprehensive research about the extraction of indium with D2EHPA and another organophosphorus extractant, 2-ethylhexyl 2-ethylhexyl-phosphonic acid (EHEHPA), from $\mathrm{H}_{2} \mathrm{SO}_{4}, \mathrm{HNO}_{3}$ and $\mathrm{HCl}$ solutions. They found that the extraction of indium was in the order $\mathrm{HNO}_{3}>\mathrm{H}_{2} \mathrm{SO}_{4}>\mathrm{HCl}$ in acid concentrations below $2 \mathrm{M}$, but in concentrated acids, the order is reversed. According to these investigators, D2EHPA is a better extractant than EHEHPA. Sato et al. $[17,18]$ concluded that, from sulfate media, only $\mathrm{In}^{3+}$ ions are extracted so the sulfate concentration 
has no effect on extraction. They also found that although significant complexation of indium with nitrate occur when the nitrate concentration is above $0.1 \mathrm{M}\left(\mathrm{c}_{\mathrm{In}, \mathrm{tot}}=3.2 \mathrm{mmol} / \mathrm{L}\right)$, the complexes are not extracted with D2EHPA or EHEHPA. This indicated that, in sulfate and nitrate media, the extraction mechanism is purely ion exchange and polymeric indium species may also form. The equation for the extraction of indium in sulfate and nitrate media may be written as follows (1) $[17, \underline{18]}$ :

$$
m \mathrm{In}^{3+}(\mathrm{aq})+(2 m+1)(\mathrm{HR})_{2}(\mathrm{org}) \rightarrow \operatorname{In}_{m} \mathrm{R}_{2(2 m+1)} \mathrm{H}_{m+2}(\mathrm{org})+3 m \mathrm{H}^{+}(\mathrm{aq})
$$

where HR is the extractant molecule.

In chloride media the corresponding reaction is

$$
m \mathrm{InCl}^{2+}(\mathrm{aq})+(m+1)(\mathrm{HR})_{2}(\text { org }) \rightarrow \mathrm{In}_{m} \mathrm{Cl}_{m} \mathrm{R}_{2(m+1)} \mathrm{H}_{2}(\text { org })+2 m \mathrm{H}^{+}(\mathrm{aq})
$$

In high hydrochloric acid concentrations (> $1 \mathrm{M})$ also solvation mechanism occurs:

$$
\mathrm{InCl}_{3}(\mathrm{aq})+(\mathrm{HR})_{2}(\mathrm{org}) \rightarrow \mathrm{InCl}_{3} \cdot 2 \mathrm{HR}(\mathrm{org})
$$

D2EHPA may also be mixed with other known extractants, typically alkylphosphates or alkylphosphine oxides, in order to improve the selectivity of extraction and stripping $[13,19]$. With other commercial extractants, some binary separations have been reported for Cyanex 923 (mixture of four trialkyl phosphineoxides) and Cyanex 272 (active extractant is bis(2,4,4-trimethylpentyl)phosphinic acid), but they both have lower loading capacity for indium than D2EHPA [20,21].

Although there are several articles on the solvent extraction of indium using D2EHPA, very few of them considered the effect of tin when present in solution with indium. One such study was that of Nikov et al. [22] who attempted to recover indium from smelting residues. They found that tin is co-extracted with indium when using D2EHPA and that it was 
necessary to use TBP to separate them. Levin et al. [23] on the other hand stated that extraction of tin(IV) is much slower than the extraction of indium suggesting that the different kinetics could be exploited in separating these metals. Tomii et al. [13] mentioned in their patent that mixture of D2EHPA and TBP has some In/Sn selectivity. In an earlier study, Golinski [24] found out that TBP has good selectivity for tin over indium from $\mathrm{HCl}$ media. He proposed the following equations for the extraction of indium and tin in $\mathrm{HCl}$ media using TBP:

$$
\begin{aligned}
& \mathrm{In}^{3+}(\mathrm{aq})+3 \mathrm{H}^{+}+3 \mathrm{Cl}^{-}+n \mathrm{TBP}(\mathrm{org}) \rightarrow \mathrm{InCl}_{3} \cdot n \mathrm{TBP}(\mathrm{org})+3 \mathrm{H}^{+}(\mathrm{aq}) \\
& \mathrm{In}^{3+}(\mathrm{aq})+4 \mathrm{H}^{+}+4 \mathrm{Cl}^{-}+n \mathrm{TBP}(\mathrm{org}) \rightarrow \mathrm{H}\left(\mathrm{InCl}_{4}\right) \cdot n \mathrm{TBP}(\mathrm{org})+3 \mathrm{H}^{+}(\mathrm{aq}) \\
& \mathrm{Sn}^{2+}(\mathrm{aq})+2 \mathrm{H}^{+}+2 \mathrm{Cl}^{-}+n \mathrm{TBP}(\text { org }) \rightarrow \mathrm{SnCl}_{2} \cdot n \mathrm{TBP}(\mathrm{org})+2 \mathrm{H}^{+}(\mathrm{aq}) \\
& \mathrm{Sn}^{2+}(\mathrm{aq})+3 \mathrm{H}^{+}+3 \mathrm{Cl}^{-}+n \mathrm{TBP}(\text { org }) \rightarrow \mathrm{H}\left(\mathrm{SnCl}_{3}\right) \cdot n \mathrm{TBP}(\mathrm{org})+2 \mathrm{H}^{+}(\mathrm{aq}) \\
& \mathrm{Sn}^{4+}(\mathrm{aq})+4 \mathrm{H}^{+}+4 \mathrm{Cl}^{-}+n \mathrm{TBP}(\text { org }) \rightarrow \mathrm{SnCl}_{4} \cdot n \mathrm{TBP}(\mathrm{org})+4 \mathrm{H}^{+}(\mathrm{aq}) \\
& \mathrm{Sn}^{4+}(\mathrm{aq})+6 \mathrm{H}^{+}+6 \mathrm{Cl}^{-}+n \mathrm{TBP}(\text { org }) \rightarrow \mathrm{H}_{2}\left(\mathrm{SnCl}_{6}\right) \cdot n \mathrm{TBP}(\text { org })+4 \mathrm{H}^{+}(\mathrm{aq})
\end{aligned}
$$

where $\mathrm{n}=2$ or $3 \mathrm{He}$ stated that at $\mathrm{HCl}$ concentrations below $2 \mathrm{M}$ extraction follows equations (4), (6) and (8) while at high $\mathrm{HCl}$ concentrations equations (5), (7) and (9).

The purpose of the present study was to explore the most appropriate experimental conditions for the acidic leaching of ITO and then use solvent extraction with D2EHPA, TBP and their mixtures as extractants to separate and concentrate indium from its acidic solutions. 


\section{Experimental}

\subsection{Reagents}

The following reagents were used in this study: indium tin oxide (ITO) nano powder (Inframat Advanced Materials, 99.99\%, particle size 30-70 nm) in the leaching experiments; $<44 \mu \mathrm{m}$ ITO (Sigma-Aldrich) as starting material. The extractants were diluted with ShellSol 2046, also known as narrow cut kerosene, (Shell Chemicals) or Exxsol D-80; D2EHPA (BDH Laboratory Supplies, assay 98\% and Baysolvex); TBP (Ajax Finechem, assay 99\% and Aldrich, assay 97\%); sulfuric, nitric and hydrochloric acids. All acids were of pro analysis purity.

\subsection{Analytical techniques}

All metal analyses of aqueous samples were carried out using ICP-AES.

\subsection{Leaching and dissolution}

For the study of the leaching of ITO, the dissolution experiments were carried out in a glass reactor by agitating $1 \mathrm{~g}$ of ITO with $1 \mathrm{~L}$ of 0.1 and $1.0 \mathrm{M} \mathrm{HCl}, \mathrm{HNO}_{3}$ and $\mathrm{H}_{2} \mathrm{SO}_{4}$ for 18 to 24 hours. A two-bladed plastic impeller was used with rotating speed of $545 \mathrm{rpm}$. In addition, batch experiments were done by shaking $0.1 \mathrm{~g}$ of ITO nano powder for 30 hours with $100 \mathrm{~mL}$ of acids of different concentrations $(0.001,0.01,0.1$, and $1 \mathrm{M})$.

The D2EHPA was washed with $6 \mathrm{M} \mathrm{HCl}$ and distilled water before use while the TBP was pretreated with $1 \mathrm{M} \mathrm{NaOH}$ and distilled water before use.

\subsection{Solvent extraction}

Three different extractant compositions were used in the solvent extraction experiments: $1 \mathrm{M}$ D2EHPA, $1 \mathrm{M}$ TBP and mixture of $0.2 \mathrm{M}$ D2EHPA $+0.8 \mathrm{M}$ TBP. The 
equilibrium experiments were carried out in either conical flasks or separatory funnels and the equilibrating time was at least $30 \mathrm{~min}$. The ITO test solutions were obtained by dissolving ITO with L/S ratio of 1000:1 to acids. The resulting solutions contained indium ( $740 \mathrm{mg} / \mathrm{L})$ and tin $(\sim 33 \mathrm{mg} / \mathrm{L}$ or $80 \mathrm{mg} / \mathrm{L}$ in the case where ITO nano powder was used).

The effect of the initial acid concentration to the extraction equilibrium was determined for every acid $\left(\mathrm{H}_{2} \mathrm{SO}_{4}, \mathrm{HCl}\right.$ and $\left.\mathrm{HNO}_{3}\right)$. For the extraction with D2EHPA the selective stripping with $\mathrm{HCl}$ was also explored. In these experiments D2EHPA was first loaded with $\mathrm{A} / \mathrm{O}=5: 1$ from ITO nano powder solution of $1 \mathrm{M} \mathrm{H}_{2} \mathrm{SO}_{4}$ and then stripped with $\mathrm{A} / \mathrm{O}=1: 1$ with $\mathrm{HCl}$ solutions of various concentrations. The contact time for both the loading and stripping was three hours.

For D2EHPA, the loading isotherm for indium from ITO solution was constructed. Test solutions of ITO in $1 \mathrm{M} \mathrm{H}_{2} \mathrm{SO}_{4}(30 \mathrm{~mL})$ were contacted for three hours with different amounts of D2EHPA. The stripping isotherm for D2EHPA with $1.5 \mathrm{M} \mathrm{HCl}$ was also constructed. D2EHPA was first loaded from ITO solution in $1 \mathrm{M} \mathrm{H}_{2} \mathrm{SO}_{4}$ with an $\mathrm{A} / \mathrm{O}=5: 1$ and then stripped using various phase ratios. 
The fractions of extraction and stripping, $E_{\mathrm{E}}$ and $E_{\mathrm{S}}$ respectively, are defined as follows:

$$
\begin{aligned}
& E_{\mathrm{E}}=\frac{c_{0, \mathrm{aq}}-c_{\mathrm{aq}}}{c_{0, \mathrm{aq}}} \cdot 100 \% \\
& E_{\mathrm{S}}=\frac{c_{0, \mathrm{org}}-c_{\mathrm{org}}}{c_{0, \mathrm{org}}} \cdot 100 \%=\frac{c_{\mathrm{aq}}}{c_{0, \mathrm{org}}} \cdot 100 \%,
\end{aligned}
$$

where $\quad c_{0, \mathrm{aq}} \quad=$ initial concentration of the metal in aqueous phase, $\mathrm{mg} / \mathrm{L}$

$c_{\mathrm{aq}}=$ equilibrium concentration of the metal in aqueous phase, $\mathrm{mg} / \mathrm{L}$

$c_{0, \text { org }}=$ initial concentration of the metal in organic phase, $\mathrm{mg} / \mathrm{L}$

$c_{\text {org }}=$ equilibrium concentration of the metal in organic phase, $\mathrm{mg} / \mathrm{L}$

\section{Results and discussion}

\subsection{Leaching and dissolution}

The apparent rates of the leaching kinetics of the oxide mixture in all the three acids were slow (Fig. 1) with that of nitric acid the slowest. A tenfold increase in acid concentration from $0.1 \mathrm{M}$ acids to $1.0 \mathrm{M}$ acids resulted in considerable increases in the rate of leaching. Complete dissolution of both metals, indium and tin, in $1 \mathrm{M} \mathrm{H}_{2} \mathrm{SO}_{4}$ and $1 \mathrm{M}$ $\mathrm{HCl}$ were achieved in 6 hours. The complete dissolution of these metals in $0.1 \mathrm{M}$ acids could not be achieved even for a day (Fig. 1).

Table 1 shows the dissolution of indium and tin in various concentrations of the three acids used. All dissolution tests were carried out for 30 hours. The results show that indium and tin have slightly different solubility in different concentrations of these acids that can be exploited in separating these metals from their combined oxides. For example, there was good selectivity with $0.01 \mathrm{M}$ and $0.1 \mathrm{M} \mathrm{H}_{2} \mathrm{SO}_{4}$ and $0.1 \mathrm{M}$ and $1.0 \mathrm{M} \mathrm{HNO}_{3}$. 

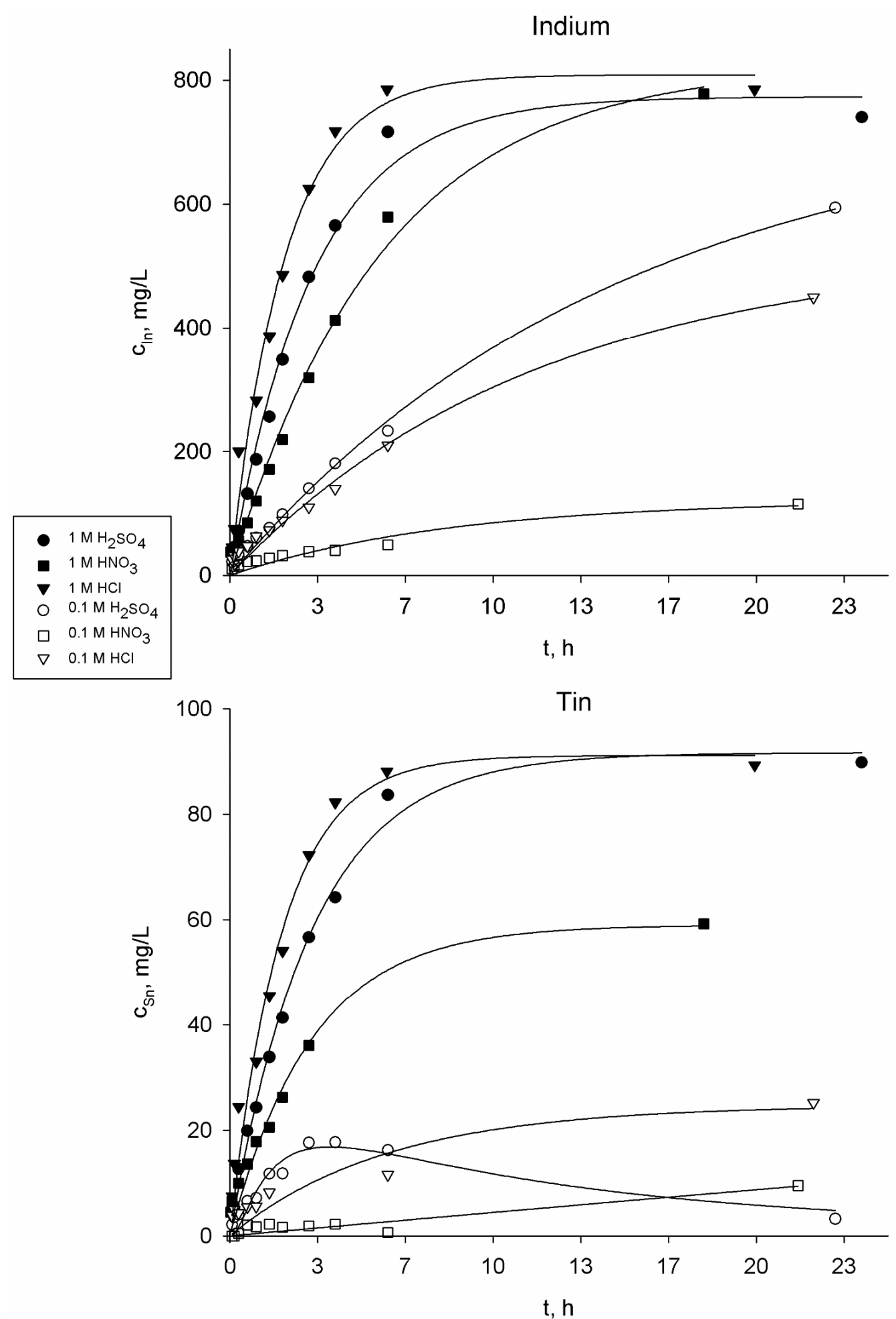

Fig. 1. Leaching of indium and tin from ITO-powder to $\mathrm{H}_{2} \mathrm{SO}_{4}, \mathrm{HCl}$ and $\mathrm{HNO}_{3}$. L/S ratio was 1000:1. 


\section{Table 1.}

Leaching and dissolution of ITO with mineral acids. $L / S=1000: 1, t=30 \mathrm{~h} . c^{0}=1 \mathrm{M}$. Yields of dissolution, $Y_{\mathrm{In}}$ and $Y_{\mathrm{Sn}}$, are calculated based on the fact that the ITO sample was composed of $90 \% \mathrm{In}_{2} \mathrm{O}_{3}$ and $10 \%$ of $\mathrm{SnO}_{2}$.

\begin{tabular}{|c|c|c|c|c|}
\hline \multicolumn{5}{|c|}{ Sulfuric acid } \\
\hline $\log c / c^{0}$ & $\begin{array}{l}c_{\ln } \\
(\mathrm{mg} / \mathrm{L})\end{array}$ & $\begin{array}{l}C_{\mathrm{Sn}} \\
(\mathrm{mg} / \mathrm{L})\end{array}$ & $\begin{array}{l}Y_{1 \mathrm{n}} \\
(\%)\end{array}$ & $\begin{array}{l}Y_{\mathrm{Sn}} \\
(\%) \\
\end{array}$ \\
\hline-3 & 35 & 0 & 5 & 0 \\
\hline-2 & 330 & 0 & 44 & 0 \\
\hline-1 & 822 & 0 & 100 & 0 \\
\hline 0 & 778 & 91.1 & 100 & 100 \\
\hline \multicolumn{5}{|c|}{ Nitric acid } \\
\hline $\log c / c^{0}$ & $\begin{array}{l}c_{\ln } \\
(\mathrm{mg} / \mathrm{L})\end{array}$ & $\begin{array}{l}c_{\mathrm{Sn}} \\
(\mathrm{mg} / \mathrm{L})\end{array}$ & $\begin{array}{l}Y_{\text {In }} \\
(\%)\end{array}$ & $\begin{array}{l}Y_{\mathrm{Sn}} \\
(\%)\end{array}$ \\
\hline-3 & 23 & 0 & 3 & 0 \\
\hline-2 & 0 & 0 & 0 & 0 \\
\hline-1 & 526 & 4.4 & 69 & 5 \\
\hline 0 & 740 & 16.1 & 100 & 21 \\
\hline \multicolumn{5}{|c|}{ Hydrochloric acid } \\
\hline $\log c / c^{0}$ & $\begin{array}{l}C_{\text {ln }} \\
(\mathrm{mg} / \mathrm{L})\end{array}$ & $\begin{array}{l}c_{\mathrm{sn}} \\
(\mathrm{mg} / \mathrm{L})\end{array}$ & $\begin{array}{l}Y_{\text {In }} \\
(\%)\end{array}$ & $\begin{array}{l}Y_{\mathrm{Sn}} \\
(\%)\end{array}$ \\
\hline-3 & 24 & 0 & 3 & 0 \\
\hline-2 & 86 & 1.2 & 12 & 2 \\
\hline-1 & 700 & 38.9 & 94 & 49 \\
\hline 0 & 749 & 81.4 & 100 & 100 \\
\hline
\end{tabular}

\subsection{Solvent extraction}

\subsubsection{Separation of indium and tin}

The separation of indium and tin by solvent extraction was studied using sample solutions of these metal ions in $\mathrm{H}_{2} \mathrm{SO}_{4}, \mathrm{HNO}_{3}$ and $\mathrm{HCl}$ media. Three different extractants were used: D2EHPA (1 M), TBP $(1 \mathrm{M})$ and a mixture of $0.2 \mathrm{M}$ D2EHPA $+0.8 \mathrm{M}$ TBP. It is helpful for the purpose of this discussion of results to state at the outset that, in nitric acid media, no separation of indium and tin was achieved with any of the extractant used including the combination of D2EHPA and TBP. Also, decreasing the concentration of the extractants by tenfold had no effect on the separation of the metals with any of the acid used. 
With D2EHPA, the selectivity for indium over tin was much higher particular at the higher end of the range of acid concentration that was investigated although a minimum of $20 \%$ tin was still extracted. In $\mathrm{HCl}$ media, the tin extraction was higher than indium, but no satisfactory separation could be achieved (Fig. 2).

With TBP, tin could be extracted when the $\mathrm{HCl}$ concentration is above $0.3 \mathrm{M}$. At 1.2 $\mathrm{M} \mathrm{HCl}$, over $97 \%$ of tin could be extracted (Fig. 3). In contrast indium did not extract until the initial $\mathrm{HCl}$ concentration was above $1.0 \mathrm{M}$. A very good separation of these metals from chloride media was therefore achieved. These results are consistent with those of Golinski [24]. In $\mathrm{H}_{2} \mathrm{SO}_{4}$ media very weak extraction and low selectivity was observed.

A good separation of indium and tin from their $\mathrm{HCl}$ solutions (1-2 $\mathrm{M})$ was also obtained when using the combination extractant (0.2 M D2EHPA + 0.8 M TBP) (Fig. 4). Around 5\% of indium, however, was co-extracted so the resulting loaded organic solution would need to be treated further. It is expected minimal co-extraction of indium in organic load in the continuous extraction. This metal can be separated in the stripping step or by scrubbing.

Another way of achieving separation between indium and tin was by selective stripping of the loaded D2EHPA with $\mathrm{HCl}$. As shown in Fig. 5, no tin was stripped over the entire range of acid concentration investigated while 94\% stripping efficiency for indium was achieved with $\mathrm{HCl}$ concentrations of $1.5 \mathrm{M}$ and above. 


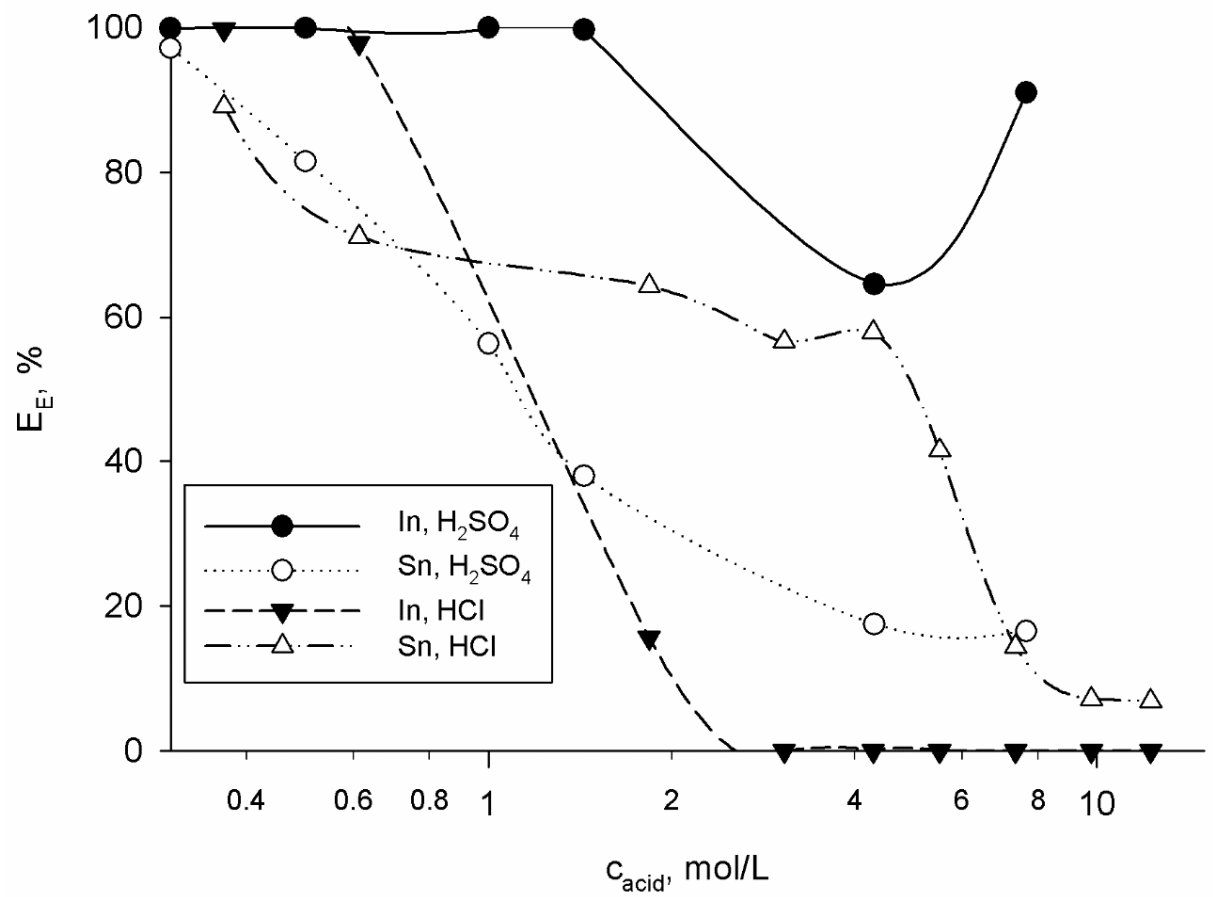

Fig. 2. Effect of initial acid concentration on extraction of indium and tin with $1 \mathrm{M}$ D2EHPA. $\mathrm{A} / \mathrm{O}=1: 1, \mathrm{c}_{0, \mathrm{In}}=392 \ldots 793 \mathrm{mg} / \mathrm{L}, \mathrm{c}_{0, \mathrm{Sn}}=10 \ldots 37 \mathrm{mg} / \mathrm{L}$. Initial metal concentrations were lower at first two points compared to others due to slow dissolution of ITO.

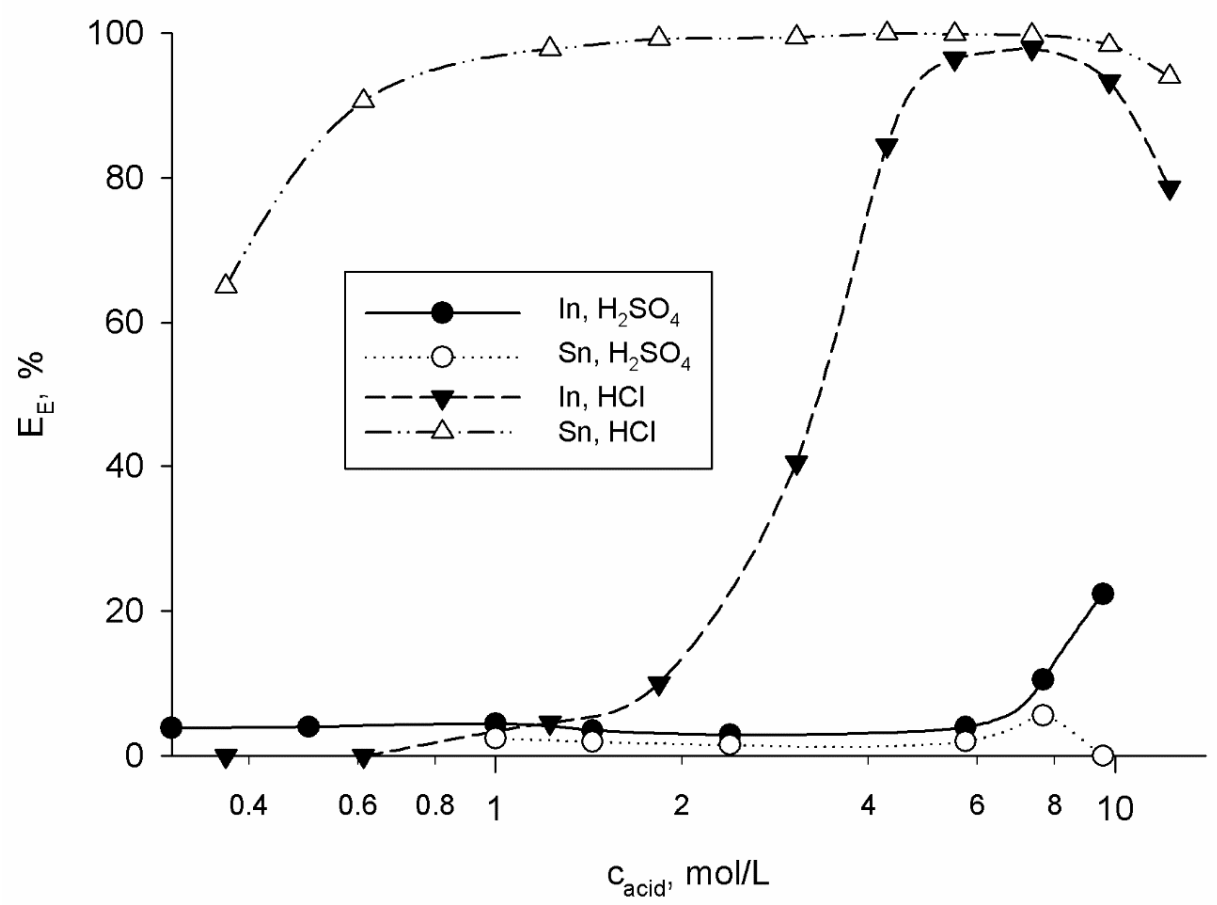

Fig. 3. Effect of initial acid concentration on extraction of indium and tin with $1 \mathrm{M}$ TBP. $\mathrm{A} / \mathrm{O}=1: 1, \mathrm{c}_{0, \mathrm{In}} \approx 700 \mathrm{mg} / \mathrm{L}, \mathrm{c}_{0, \mathrm{Sn}} \approx 33 \mathrm{mg} / \mathrm{L}$. 


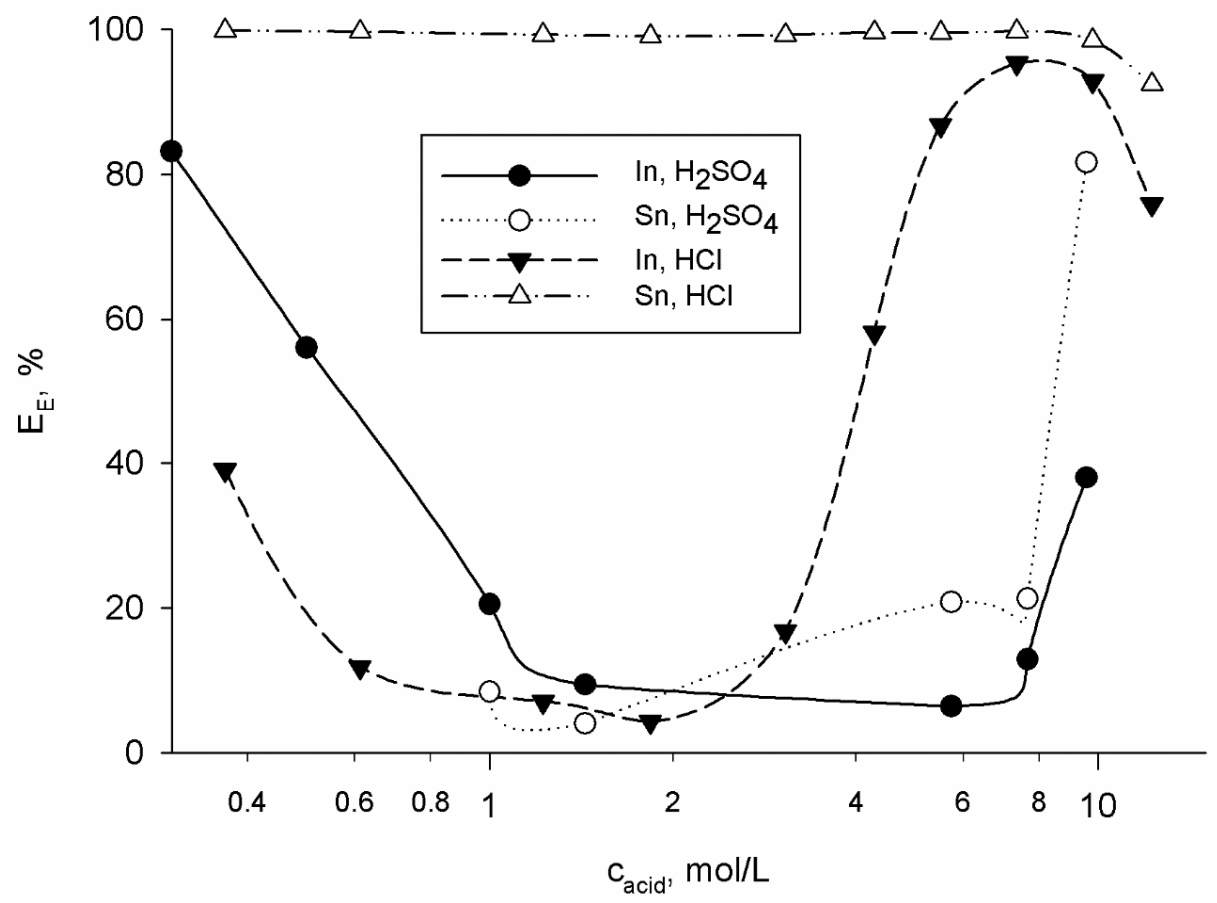

Fig. 4. Effect of initial acid concentration on extraction of indium and tin with mixture of $0.2 \mathrm{M}$ D2EHPA and $0.8 \mathrm{M}$ TBP. A/O = 1:1, $\mathrm{c}_{0, \mathrm{In}} \approx 700 \mathrm{mg} / \mathrm{L}, \mathrm{c}_{0, \mathrm{Sn}} \approx 32 \mathrm{mg} / \mathrm{L}$.

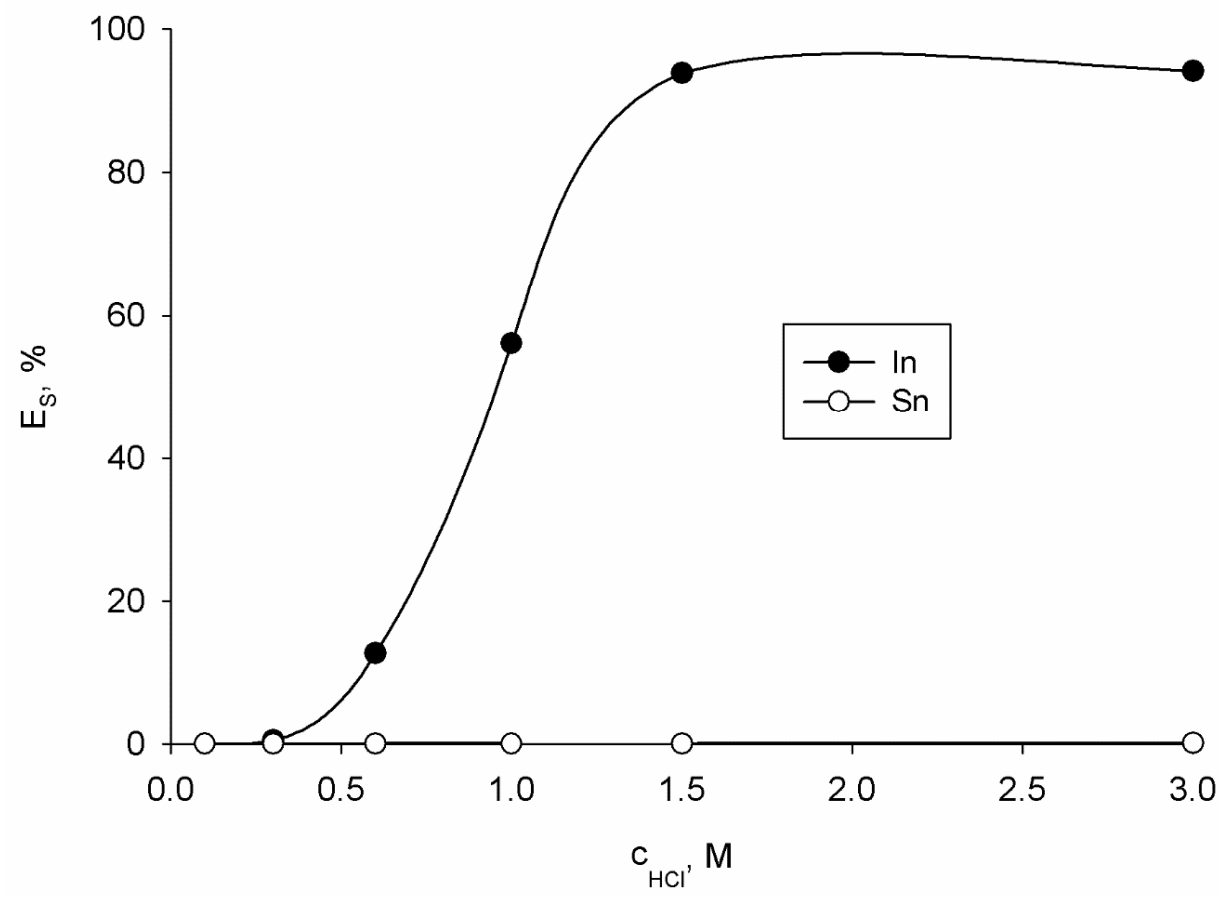

Fig. 5. Effect of initial $\mathrm{HCl}$ concentration on the stripping of indium and tin from $20 \%$ D2EHPA. A/O = 1:1, $\mathrm{c}_{0, \mathrm{In}, \text { org }}=3.35 \mathrm{~g} / \mathrm{L}, \mathrm{c}_{0, \mathrm{Sn}, \text { org }}=0.26 \mathrm{~g} / \mathrm{L}$. 


\subsubsection{McCabe-Thiele analysis}

D2EHPA is known to have very good loading capacity for indium from $1 \mathrm{M}$ sulfuric acid [14]. In our experiments (Fig. 6), when the equilibrium concentration in aqueous phase was $0.49 \mathrm{~g} / \mathrm{L}$, the distribution coefficient was 15.3 and full loading was still not achieved. For tin, the loading capacity was found to be around $0.39 \mathrm{~g} / \mathrm{L}$.

Based on extraction and stripping stages described below (Figs. 6 and 7), a scheme for solvent extraction unit operation is given (Fig. 8). The McCabe-Thiele plot in Fig. 6 shows indium extraction with two countercurrent stages with $\mathrm{A} / \mathrm{O}=8: 1$. Analysis of data indicated that $6.2 \mathrm{~g} / \mathrm{L}$ indium containing organic phase can achieved starting from $0.74 \mathrm{~g} / \mathrm{L}$ aqueous solution with recovery of indium over $99 \%$. Corresponding analysis was also done for the stripping of the loaded D2EHPA with $1.5 \mathrm{M} \mathrm{HCl}$. According to the McCabe-Thiele plot, a $6.2 \mathrm{~g} \mathrm{In} / \mathrm{L}$ loaded D2EHPA can be stripped to $0.35 \mathrm{~g} / \mathrm{L}$ with $\mathrm{A} / \mathrm{O}=1: 2$ in two countercurrent stages (Fig. 7). This yielded an $\mathrm{HCl}$ strip solution containing $12.2 \mathrm{~g} / \mathrm{L}$ indium. The maximum concentration of tin in these stripping solutions was $0.022 \mathrm{~g} / \mathrm{L}$. Under these conditions of metal ion concentrations, indium may be recovered by cementation [22]. 


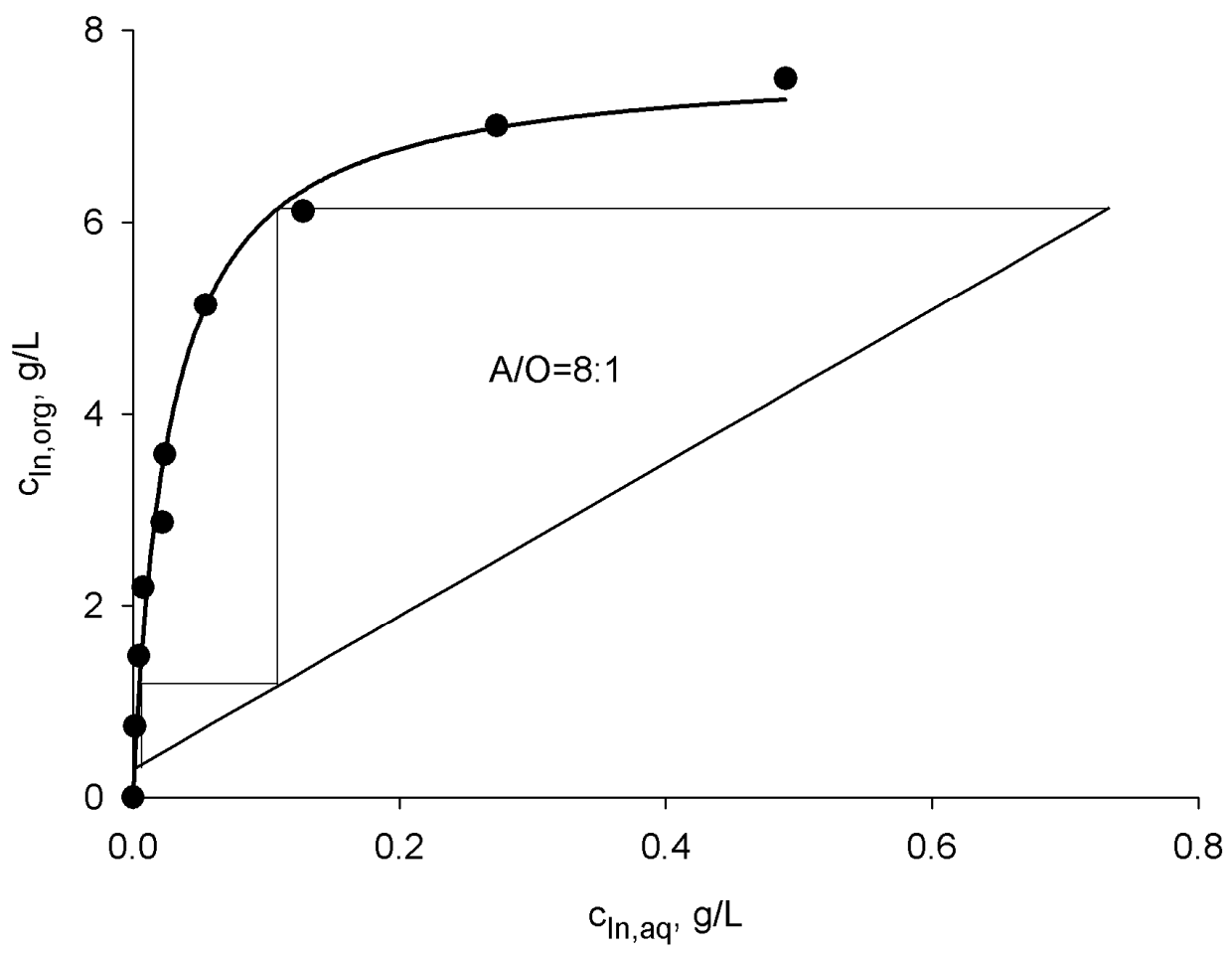

Fig. 6. McCabe-Thiele diagram for the extraction of indium with $20 \%$ D2EHPA from $1 \mathrm{M}$ $\mathrm{H}_{2} \mathrm{SO}_{4}$.

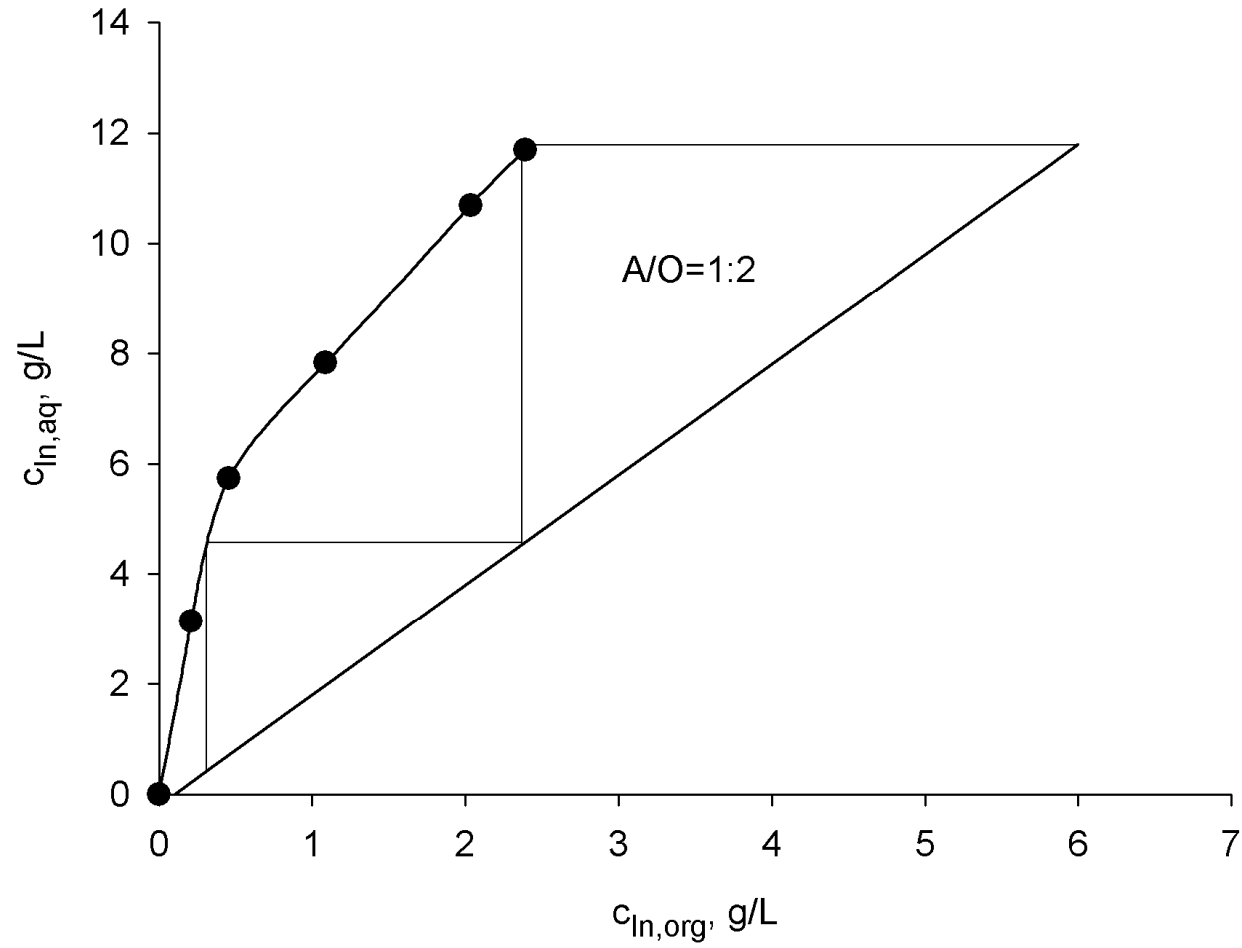

Fig. 7. McCabe-Thiele diagram for the stripping of indium from $20 \%$ D2EHPA with $1.5 \mathrm{M}$ $\mathrm{HCl}$. 


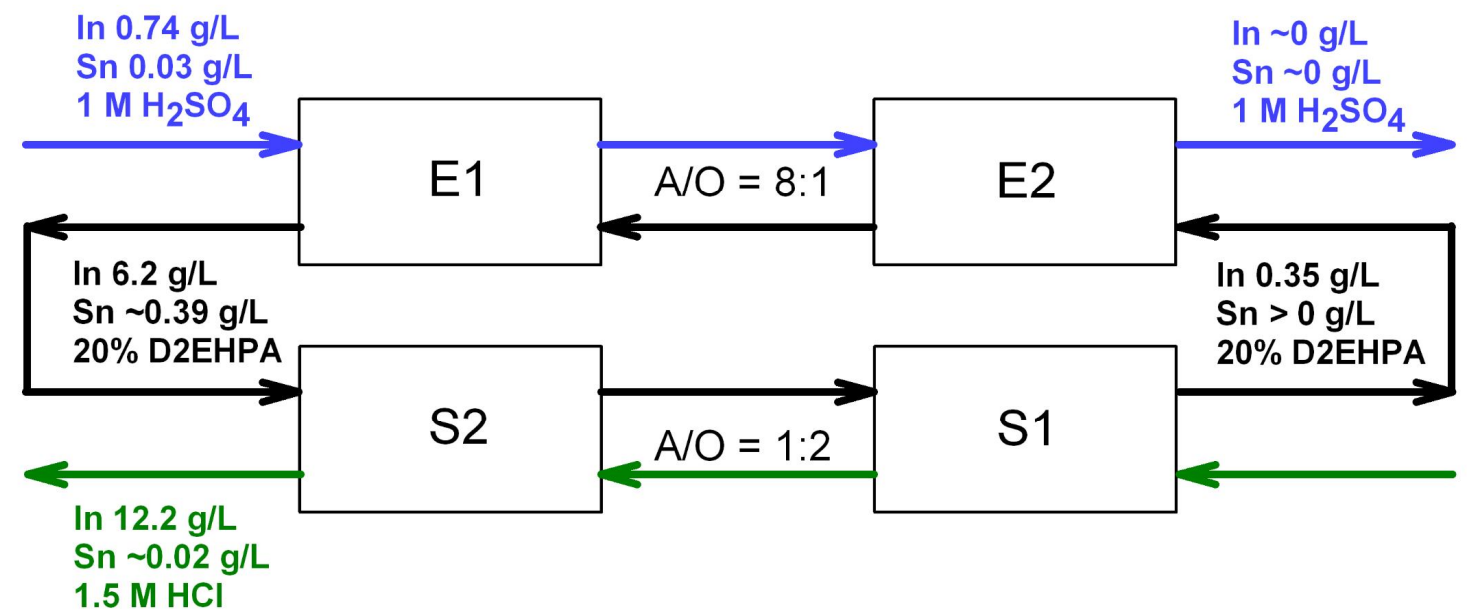

Fig. 8. Suggested flow sheet for solvent extraction recovery of indium from $1 \mathrm{M} \mathrm{H}_{2} \mathrm{SO}_{4}$ containing tin as an impurity. Phase ratios are for extraction (E1 and E2) A/O = 8:1 and for stripping (S1 and $\mathrm{S} 2) \mathrm{A} / \mathrm{O}=1: 2$.

\section{Conclusions}

The present work showed that, in terms of leaching, the apparent rates of dissolution of indium tin oxide (ITO) in acidic media were slow but best achieved with either $\mathrm{H}_{2} \mathrm{SO}_{4}$ or $\mathrm{HCl}$ as the apparent dissolution rates in these acids are comparable and faster than that in $\mathrm{HNO}_{3}$. Given that $\mathrm{H}_{2} \mathrm{SO}_{4}$ is less corrosive to process equipment than $\mathrm{HCl}$, it has a slight advantage over the latter. The apparent rate of dissolution of ITO increases with increases in acid concentration and the acid concentration may be exploited to achieve some selectivity of dissolution.

In terms of separation and purification of the dissolved indium and tin, three different solvent extraction systems were studied for separation of these metals. Tin could be selectively extracted from its $\mathrm{HCl}$ solutions with either $1 \mathrm{M} \mathrm{TBP}$ or with a mixture of $0.2 \mathrm{M}$ D2EHPA and 0.8 M TBP. With both solvent systems, the $\mathrm{HCl}$ concentration that yielded optimal extraction was around $1.5 \mathrm{M}$. Another way was to extract both metals from their $\mathrm{H}_{2} \mathrm{SO}_{4}$ solutions with D2EHPA and then selectively strip indium with $>1.5 \mathrm{M} \mathrm{HCl}$. This route of selective stripping is the most attractive because D2EHPA has a very high loading 
capacity for indium (7.5 g/L in $0.49 \mathrm{~g} / \mathrm{L}$ of aqueous concentration). McCabe-Thiele analysis of this solvent system revealed that with two countercurrent stages $(\mathrm{A} / \mathrm{O}=1: 8)$ of extraction and two countercurrent stages $(\mathrm{A} / \mathrm{O}=2: 1)$ of stripping, indium could be concentrated from $0.74 \mathrm{~g} / \mathrm{L}$ to $12.2 \mathrm{~g} / \mathrm{L}$ and almost complete indium recovery from the leaching solution and high In/Sn selectivity in stripping could be achieved. These results show that solvent extraction is an effective method of concentrating indium and separating it from tin and therefore applicable for recovering indium from ITO.

\section{Acknowledgments}

Authors want to thank Mr. Miikka Tulonen and Mr. Kari Valkama for cooperation within this work. Thanks also to the Graduate School in Chemical Engineering for financial support. 


\section{References}

[1] A.C. Tolcin, Indium 2008, U.S. Geological Survey, 2008.

[2] A.C. Tolcin, Indium 2009, U.S. Geological Survey, 2009.

[3] J.C. Bailar, H.J. Emeleus, R. Nyholm, A.F. Trotman-Dickenson, Comprehensive Inorganic Chemistry, 1st ed., Oxford, Pergamon, 1973.

[4] J. Kleinberg, W.J. Argersinger, E. Griswold, Inorganic chemistry, Boston, D.C. Heath and Company, 1960.

[5] Mineral Information Institute - INDIUM, (www.mii.org, 18.6.2010).

[6] MinorMetals Prices, (www.minormetals.com, 18.6.2010).

[7] K. Ryoshi, Y. Hattori, H. Kobayashi, Method of manufacturing powder containing indium oxide as a main component, JP2008137825, 2008.

[8] C. Lee, Y. Peng, S. Tsai, A method for the recovery of indium-tin-oxides coating from scrap glass substrate, TW286953, 2007.

[9] Z. Chen, J. Chen, Y. Zhou, J. Yao, X. Wang, Recycling of indium from indium-tinoxide wastes, CN1420184, 2003.

[10] T. Shimofusa, H. Abe, Y. Kikuchi, W. Hasegava, Separation of indium, JP2000128531, 2000.

[11] A.M. Alfantazi, R.R. Moskalyk, Processing of indium: a review, Minerals Engineering. 16 (2003) 687-694.

[12] A. Paiva, Recovery of Indium from Aqueous Solutions by Solvent Exctraction, Separation Science and Technology. 36 (2001) 1395-1419.

[13] K. Tomii, H. Tsuchida, United States Patent: 4292284 - Solvent extraction recovery process for indium, U.S. Patent 4292284, 1981.

[14] P. Fossi, E. Sambarino, Process for the Recovery of Indium, U.S. Patent 4372922, 1983.

[15] J. Ke, R. Qiu, C. Chen, Recovery of metal values from copper smelter flue dust, Hydrometallurgy. 12 (1984) 217-224.

[16] S. Li, M. Tang, J. He, S. Yang, C. Tang, Y. Chen, Extraction of Indium from IndiumZinc Concentrates, Trans. Nonferrous Met. Soc. China. 16 (2006) 1448-1454.

[17] T. Sato, K. Sato, Liquid-liquid extraction of indium (III) from aqueous acid solutions by acid organophosphorus compounds, Hydrometallurgy. 30 (1992) 367-383.

[18] T. Sato, The extraction of indium(III), lanthanum(III) and bismuth(III) from sulphuric acid solutions by di-(2-ethylhexyl)-phosphoric acid, Journal of Inorganic and Nuclear Chemistry. 37 (1975) 1485-1488.

[19] W.A. Rickelton, United States Patent: 5344567 - Recovery of indium by solvent extraction using trialkylphosphine oxides, U.S. Patent 5344567, 1994.

[20] B. Gupta, A. Deep, P. Malik, Liquid-liquid extraction and recovery of indium using Cyanex 923, Analytica Chimica Acta. 513 (2004) 463-471.

[21] B. Gupta, N. Mudhar, I. Singh, Separations and recovery of indium and gallium using bis(2,4,4-trimethylpentyl)phosphinic acid (Cyanex 272), Separation and Purification Technology. 57 (2007) 294-303.

[22] B. Nikov, P. Stojanov, T. Stojadinovic, Production of indium from Imperial Smelting Process residues, in: Proceedings of Hydrometallurgy '94, Cambridge, Chapman and Hall, 1994: pp. 1153-1164.

[23] I. Levin, A. Shatalova, T. Azarenko, I. Vorsina, N. Burtovaya-Balakireva, T. Rodina, Concentration and separation of indium, gallium, thallium, antimony and bismuth by extraction with alkylphosphoric acids, Talanta. 14 (1967) 801-808.

[24] M. Golinski, Extraction of tin and indium with tributyl phosphate from hydrochloric acid solutions, in: Proceedings of the International Solvent Extraction Conference (ISEC'71), London, 1971: pp. 603-615. 
